\title{
Pengembangan Modul Bilingual Bergambar Berbasis Quantum Learning pada Materi Peluang
}

\author{
Ageng Sandiyanti ${ }^{*}$, Rosida Rakhmawati $\mathbf{M}^{1}$ \\ ${ }^{1}$ Universitas Islam Negeri Raden Intan Lampung. Jalan Endro Suratmin, Sukarame, Bandar \\ Lampung 35133, Indonesia. \\ *Corresponding Author. E-mail: Ageng1812@gmail.com, Telp: +62858413457434
}

Received : 13-02-2018; Revised : 13-05-2018; Accepted : 30-05-2018

\begin{abstract}
Abstrak
Penelitian ini bertujuan untuk menghasilkan produk berupa modul bilingual bergambar berbasis quantum learning pada materi peluang. Penelitian ini termasuk jenis penelitian dan pengembangan (Research and Development) mengacu pada model yang terdiri atas lima langkah kegiatan yaitu analisys, design, development, implementation, dan evaluation. Hasil penelitian menunjukkan bahwa modul yang dihasilkan memperoleh nilai persentase rata-rata dari ahli materi yaitu $83,33 \%$ dengan kriteria sangat baik, nilai persentase rata-rata dari ahli media yaitu $85 \%$ dengan kriteria sangat baik dan nilai persentase rata-rata dari ahli bahasa yaitu $78,67 \%$ dengan kriteria sangat baik. Modul bilingual bergambar berbasis quantum learning pada meteri peluang juga memperoleh nilai persentase dari respon siswa sebesar $80 \%$ dengan kriteria sangat baik dan memperoleh nilai persentase dari pendidik sebesar 84\% dengan kriteria sangat baik.
\end{abstract}

Kata Kunci: Pengembangan Modul bilingual bergambar, Quantum Learning

\begin{abstract}
This study aims to produce products in the form of bilingual module based on quantum learning on the material opportunities. This research includes the type of research and development (Research and Development) refers to a model consisting of five steps of activities namely analysis, design, development, implementation, and evaluation. The result of the research shows that the module that obtained the average percentage value from the material expert is $83,33 \%$ with the very good criterion, the average percentage value from media expert is $85 \%$ with very good criteria and the average percentage value from the linguist ie $78.67 \%$ with very good criteria. The bilingual module based on quantum learning on the opportunity meters also obtained a percentage value of $80 \%$ student response with very good criteria and obtained the percentage value of educator equal to $84 \%$ with very good criteria.
\end{abstract}

Keywords: Development of bilingual pictorial module, Quantum Learning

\section{PENDAHULUAN}

Jam mata pelajaran matematika di sekolah mendapat porsi lebih banyak dibanding pelajaran lainnya. Matematika juga termasuk mata pelajaran yang menjadi standar untuk diujikan ketika akan melanjutkan kejenjang pendidikan yang lebh tinggi. Matematika merupakan ilmu yang sangat berperan penting dalam kehidupan dan merupakan cabang ilmu yang bermanfaat untuk terjun dan bersosialisasi di masyarakat (Purwanti, 2016). Kenyataan masalah yang dihadapi yaitu kemampuan siswa dalam menyelesaikan soal matematika masih rendah, hal ini disebabkan saat belajar matematika siswa cenderung menghafal rumus, hanya meniru contoh soal yang diberikan oleh guru, sehingga tiap kali diberi soal yang berbeda, siswa belum mampu mengerjakan soal tersebut, meskipun siswa telah diberikan buku pegangan matematika (Anggoro, 2015).

Salah satu upaya yang dapat dilakukan oleh guru untuk mengurangi 
kesulitan belajar pada siswa adalah dengan mengembangkan bahan ajar. Bahan ajar adalah seperangkat materi yang disusun secara sistematis, baik tertulis maupun tidak tertulis sehingga menciptakan lingkungan atau suasana yang memungkinkan siswa untuk belajar (Hamdani, 2011). Selain bahan ajar model pembelajaran juga bisa membantu mengurangi kesulitan dalam belajar, salah satunya yaitu model pembelajaran Quantum Learning. Quantum Learning merupakan pembelajaran yang mempunyai karakteristik yang cocok dengan pemberian pengalaman belajar siswa (Y. K. Sari, Mulyani, Susilowati, \& Ridlo, 2013). Hal ini diperkuat oleh pendapat Nanang (2015) agar kegiatan belajar mengajar di kelas berjalan sesuai dengan kompetensi dasar yang diharapkan kelengkapan pembelajaran seperti guru, buku ajar, sarana dan prasarana sangat perlu disiapkan.

Mengacu pada beberapa penelitian terdahulu yang menghasilkan bahan ajar diantaranya. Penelitian yang dilakukan oleh Rully Anggraini, melakukan penelitian berupa pengembangan bahan ajar, dengan berbantuan software imindmap, pada materi trigonometri (Anggraini, 2016). Penelitian selanjutnya yang dilakukan oleh Fiska Komala Sari, telah melakukan penelitian berupa pengembangan media pembelajaran dalam bentuk modul menggunakan aplikasi geogebra pada pokok bahasan turunan (F. K. Sari, Farida, \& Syazali, 2016). Penelitian berikutnya yang juga mengembangkan produk yaitu penelitian Aji Arif Nugroho, produk yang dikembangkankan yaitu media pembelajaran berupa blog, materi dalam penelitian sama dengan materi sebelumnya yang dilakukan oleh Rully Anggraini yaitu materi trigonometi (Nugroho, Putra, Putra, \& Syazali, 2017). Penelitian tersebut sama-sama mengembangkan produk berupa software dan aplikasi, produk yang dihasilkan bukan produk yang dicetak.

Penelitian yang dilakukan oleh Puspita telah mengembangkan produk berupa modul, telah dilengkapi gambar dan terdapat dua bahasa (Puspita, 2014). Penelitian selanjutnya yang dilakukan oleh Bambang Sri Anggoro mengembangkan produk berupa modul matematika, modul telah menerapkan strategi problem solving selain itu modul tersebut juga digunakan mengukur tingkat kemampuan berpikir kreatif matematis siswa (Anggoro, 2015). Penelitian lain menghasilkan produk media pembelajaran berupa buku saku fisika dilakukan oleh Mustari. (Mustari \& Sari, 2017). Kesamaan ketiga penelitian selain sama-sama mengembangkan produk juga menghasilkan produk yang merupakan jenis produk yang dicetak.

Beberapa penelitian yang menggunakan model pembelajaran Quantum diantaranya. Penelitian yang dilakukan oleh Yunita Kartika Sari, yang melakukan penerapan metode Quantum pada pendekatan jelajah alam sekitar berbasis karakter dan konservasi mendapatkan hasil bahwa model

Quantum efektif diterapkan untuk meningkatkan aktivitas dan hasil belajar siswa (Y. K. Sari et al., 2013). Penelitian selanjutnya dilakukan oleh Rendya Logina Linto yang juga menggunakan metode pembelajaran Quantum yang menyimpulkan bahwa pembelajaran dengan metode Quantum membuat kemampuan koneksi matematika siswa lebih baik (Linto, Elniati, \& Rizal, 2012). Penelitian yang dilakukan oleh Hesti Muldi Susanti, dengan menerapkan model Quantum dapat meningkatkan pembelajaran matematika (Susanti, 2013)

Berdasarkan pada penelitian terdahulu peneliti akan mengembangkan produk yang baru dan berbeda dari penelitian terdahulu 
Desimal, 1 (2), 2018 - 159

Ageng Sandiyanti, Rosida Rakhmawati M

produk yang peneliti kembangkan berupa modul dilengkapi bilingual juga disertai gambar dan berbasis Quantum Learning pada materi peluang.

\section{METODE}

Penelitian ini menggunakan metode penelitian dan pengembangan (Research and Development). Research and Development merupakan metode penelitian yang digunakan untuk menghasilkan produk tertentu dan menguji keefektifan produk tersebut. Penelitian ini mengacu pada model Dick \& Carrey yaitu model ADDIE, model ini meliputi 1) analysis, 2) design, 3) development, 4) implementation, 5) evaluation (Tegeh, Jampel, \& Ketut Pudjawan, 2014).

Pelaksanaan penelitian dan pengembangan, peneliti menggunakan dua jenis data yang dikumpulkan yaitu, data kuantitatif dan data kualitatif. Teknik pengumpulan data yang digunakan untuk mendapatkan data mengenai respon siswa terhadap modul bilingual bergambar berbasis quantum learning menggunakan kuesioner dan wawancara.

Instrumen yang digunakan dalam penelitian dan pengembangan modul bilingual bergambar berbasis quantum learning pada materi peluang yaitu: Lembar validasi digunakan untuk mengetahui apakah modul dan instrumen yang telah dirancang valid atau tidak.

Angket validator bertujuan untuk mengetahui kevalidan serta pemberian kritik dan saran pada modul bilingual bergambar berbasis quantum learning pada meteri peluang kelas VII, yang meliputi ahli desain, ahli bahasa dan ahli materi. Angket respon guru bertujuan untuk mengetahui respon terhadap pembelajaran tersebut, serta kelayakan modul bilingual bergambar berbasis quantum learning pada meteri peluang. Angket respon siswa digunakan untuk mengetahui respon siswa terhadap modul bilingual bergambar berbasis quantum learning pada meteri peluang yang dikembangkan.

Instrumen yang digunakan memiliki 4 jawaban, yaitu sangat baik diberi skor 4 , cukup baik diberi skor 3 , tidak baik skor 2, sangat tidak baik diberi skor 1 . Lebih jelasnya apat dilihat pada Tabel 1 .

Tabel 1. Pedoman Skor Penilaian

\begin{tabular}{cc} 
Skor & Kriteria \\
4 & Sangat baik \\
3 & Cukup Baik \\
2 & Tidak Baik \\
1 & Sangat Tidak Baik \\
\hline
\end{tabular}

Selanjutnya dilakukan perhitungan tiap butir pertanyaan menggunakan rumus sebagai berikut (Sugiyono, 2013):

$$
\mathrm{P}=\frac{\sum x}{\text { skor maksimal }} \times 100 \%
$$

Keterangan :

$\mathrm{P}=$ Persentase kelayakan

$\sum x=$ jumlah skor

Langkah terakhir adalah menyimpulkan hasil perhitungan berdasarkan aspek dengan melihat Tabel 2.

Tabel 2. Range Persentase dan Kriteria

\begin{tabular}{lc}
\multicolumn{2}{c}{ Kulitatif Modul } \\
\hline Skor Persentase & Kriteria \\
$75 \% \leq p \leq 100 \%$ & Sangat baik \\
$50 \% \leq p<75 \%$ & Cukup Baik \\
$25 \% \leq p<50 \%$ & Tidak Baik \\
$0 \% \leq p<25 \%$ & Sangat Tidak Baik \\
\hline
\end{tabular}

Produk pengembangan akan berakhir saat skor penilaian terhadap modul ini telah memenuhi syarat kelayakan dengan tingkat kesesuaian materi dan desain, dikategorikan sangat menarik atau manarik.

\section{HASIL DAN PEMBAHASAN}

Hasil pengembangan ini berupa produk berupa modul bilingual bergambar berbasis quatum learning pada meteri peluang menggunakan prosedur dan pengembangan ADDIE 
yang dilakukan dari tahap pertama analyze (analisis), kedua yaitu Design (perancangan), tahap ketiga yaitu Develop (pengembangan), dan terakhir tahap Implementation (penerapan) dan Evaluation (evaluasi).

Analyze (Analisis) yaitu berupa hasil wawancara kepada guru matematika dan kuesioner yang dibagikan kepada siswa. Analisis dilakukan untuk mengetahui masalah yang ada di lapangan. Tahap kedua yaitu design (perancangan) berupa pemilihan bahan ajar yang dipilih yaitu berupa modul bilingual bergambar. Materi yang dipilih materi peluang. Pemilihan gambar membantu siswa untuk memahami materi tersebut. Metode yang digunakan yaitu metode quantum learning.

Tahap selanjutnya yaitu development (pengembangan). Tahap ini merupakan tahap penyusunan modul menjadi satu kesatuan utuh. Modul yang telah selesai didesain, selanjutnya divalidasi oleh validator. Tahap berikutnya yaitu tahap implementation (penerapan) modul yang sudah divalidasi kemudian diuji cobakan kepada peserta didik dan pendidik. tahap akhir yaitu evaluation (evaluasi) berupa keseluruhan proses dari tahap satu sampai tahap empat dan perhitungan hasil penilaian para validator.

Penilaian validasi pada ahli materi melalui dua tahap, yaitu tahap 1 dan tahap 2. Hasil penilaian validasi tahap 1 dan tahap 2 dapat dilihat pada Tabel 3.

Tabel 3. Penilaian Validasi Ahli Materi

\begin{tabular}{ccc} 
& $\begin{array}{c}\text { Persentase } \\
\text { Rata - Rata }\end{array}$ & Kriteria \\
Tahap 1 & $62 \%$ & Cukup baik \\
Tahap 2 & $85,33 \%$ & Sangat baik \\
\hline
\end{tabular}

Terlihat pada Tabel 3. penilaian validasi ahli materi tahap 1 memperoleh persentase rata-rata sebesar $62 \%$ dengan kriteria cukup baik, pada penilaian validasi tahap 2 memperoleh persentase rata-rata sebesar $85,33 \%$ dengan kriteria sangat baik. Penilaian ini juga disajikan dalam bentuk grafik pada Gambar 1 .

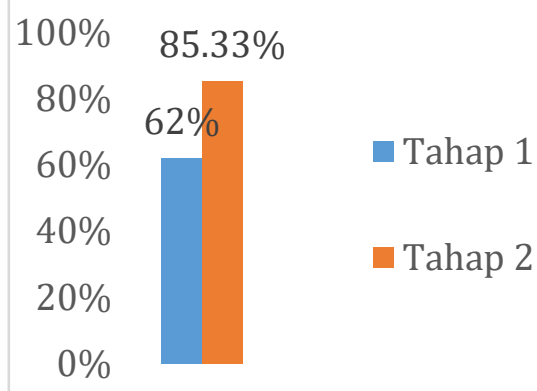

Gambar 1. Grafik validasi ahli materi

Terlihat pada Gambar 1. Grafik Penilaian validasi ahli materi pada tahap 1 yaitu $62 \%$ kemudian mengalami peningkatan pada tahap 2 menjadi 85,33\%. Peningkatan terjadi setelah dilakukannya perbaikan produk sesuai saran dari validator. Saran berupa perbaikan pada gambar yaitu mengganti gambar yang lebih sesuai dengan materi gambar kura-kura yang terlihat pada Gambar 2. Sesuai dengan saran validator peneliti mengganti dengan gambar dadu yang terlihat pada Gambar 3.

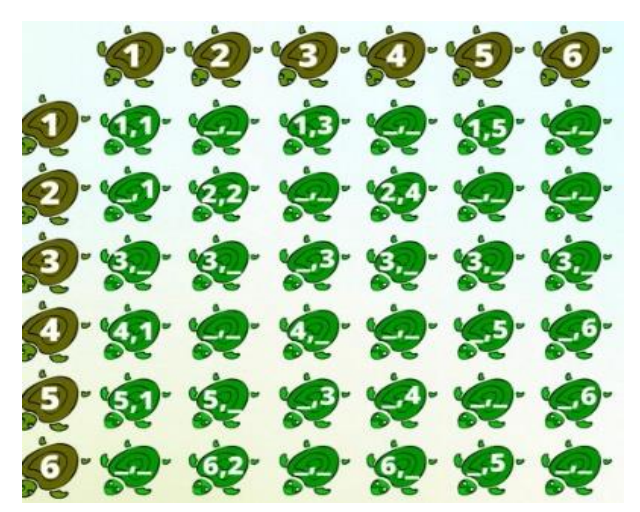

Gambar 2. Sebelum revisi 
Desimal, 1 (2), 2018 - 161

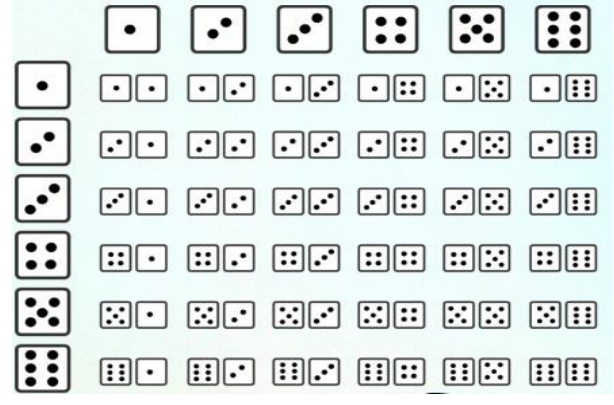

Gambar 3. Setelah revisi

Selain ahli materi validasi juga dilakukan oleh ahli media. Penilaian validasi oleh ahli media melalui dua tahap yaitu tahap 1 dan tahap 2. Hasil penilaian validasi tahap 1 dan tahap 2 dapat dilihat pada Tabel 4 .

Tabel 4. Hasil Penilian Validasi Ahli Media

\begin{tabular}{ccc}
\hline & $\begin{array}{c}\text { Persentase } \\
\text { Rata - Rata }\end{array}$ & Kriteria \\
Tahap 1 & $77 \%$ & Sangat baik \\
Tahap 2 & $85 \%$ & Sangat baik \\
\hline
\end{tabular}

Terlihat pada Tabel 4. penilaian validasi ahli media tahap 1 memperoleh persentase rata-rata sebesar $77 \%$ dengan kriteria cukup baik, pada penilaian validasi tahap 2 memperoleh persentase rata-rata sebesar 85\% dengan kriteria sangat baik. Penilaian ini juga disajikan dalam bentuk grafik pada Gambar 4 .

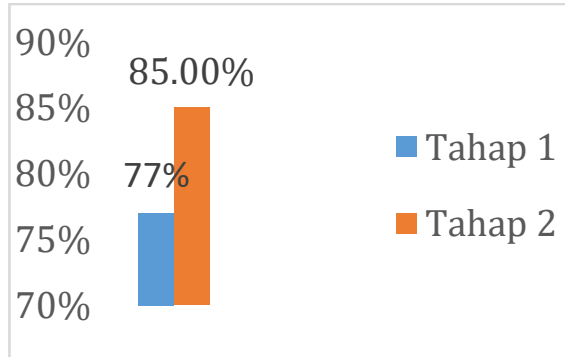

Gambar 4. Grafik validasi ahli media

Terlihat pada Gambar 4. Grafik Penilaian validasi ahli media pada tahap 1 yaitu 77\% mengalami peningkatan pada tahap 2 menjadi $85 \%$. Peningkatan terjadi setelah dilakukannya perbaikan produk sesuai saran dari validator. Saran berupa perbaikan pada sampul modul, yaitu mengganti sampul modul awal. Sampul modul awal masih belum menarik perhatian siswa untuk mau membaca modul dan terlihat seperti sampul buku-buku resmi. Terlihat pada Gambar 5. Sesuai saran dari validator peneliti mengganti gambar sampul dengan karakter supaya menarik. Terlihat pada Gambar 6.

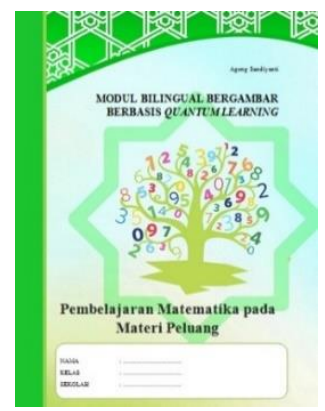

Gambar 5. Sebelum revisi

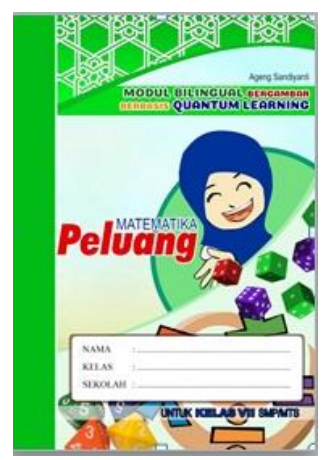

Gambar 6. Setelah revisi

Selain ahli materi dan media validasi juga dilakukan oleh ahli bahsa

Tabel 5. Hasil Validasi Ahli Bahasa

\begin{tabular}{ccc}
\hline & $\begin{array}{c}\text { Persentase } \\
\text { Rata - Rata }\end{array}$ & Kriteria \\
Tahap 1 & $69,5 \%$ & cukup baik \\
Tahap 2 & $78,67 \%$ & Sangat baik \\
\hline
\end{tabular}

Berdasarkan Tabel 4. penilaian validasi ahli bahasa tahap 1 memperoleh persentase rata-rata sebesar 69,5\% dengan kriteria cukup baik, pada penilaian validasi tahap 2 
Desimal, 1 (2), 2018 - 162

Ageng Sandiyanti, Rosida Rakhmawati M

memperoleh persentase rata-rata sebesar 78,67\% dengan kriteria sangat baik. Penilaian ini juga disajikan dalam bentuk grafik pada Gambar 7.

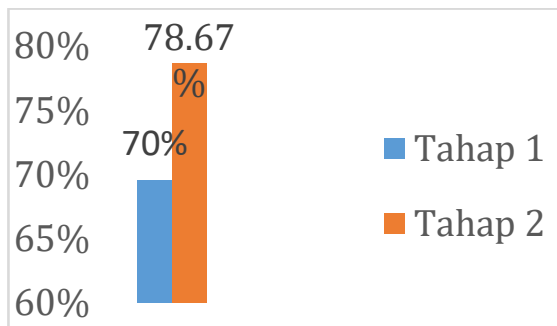

Gambar 7. Grafik validasi ahli media

Terlihat pada Gambar 7. Grafik Penilaian validasi ahli bahasa pada tahap 1 yaitu $70 \%$ mengalami peningkatan pada tahap 2 menjadi 78,67\%. Peningkatan terjadi setelah dilakukannya perbaikan bahasa pada produk sesuai saran dari validator. Saran berupa perbaikan pada kalimat tanya dan kalimat perintah, pemilihan diksi dan keefektifan kalimat.

Hasil uji coba peserta didik dilakukan melalui dua tahapan yaitu uji kelompok kecil dan uji lapangan mengalami peningkatan rata-rata skor pada aspeknya, Penilaian hasil uji coba dapat dilihat juga pada Tabel 8.

Tabel 6. Hasil Uji Coba Kelompok Kecil

\begin{tabular}{cccc} 
Respon & Jumlah & $\begin{array}{c}\text { Persentase } \\
\text { Kelayakan }\end{array}$ & Kriteria \\
1 & 32 & $72 \%$ & CB \\
2 & 40 & $90 \%$ & SB \\
3 & 33 & $75 \%$ & SB \\
4 & 34 & $77 \%$ & SB \\
5 & 37 & $84 \%$ & SB \\
6 & 33 & $75 \%$ & SB \\
7 & 31 & $70 \%$ & CB \\
8 & 36 & $82 \%$ & SB \\
9 & 36 & $82 \%$ & SB \\
10 & 32 & $72 \%$ & CB \\
Jumlah & $\mathbf{3 4 4}$ & $\mathbf{7 7 , 9}$ & $\bar{p}=\mathbf{7 7 , 9 \%}$ \\
\hline
\end{tabular}

Berdasarkan Tabel 6. hasil penilaian uji coba kelompok kecil yang berjumlah 10 siswa mendapatkan nilai total keseluruhan persentase kelayakan sebesar 77,9\% dengan kiteria sangat baik. Setelah melakukan uji coba kelompok kecil peneliti melakukan uji coba Lapangan dan mendapatkan penilaian dari siswa seperti terlihat pada Tabel 7.

Tabel 7. Hasil Uji Coba Lapangan

\begin{tabular}{cccc}
\hline Respon & Jumlah & $\begin{array}{c}\text { Persentase } \\
\text { Kelayakan }\end{array}$ & Kriteria \\
1 & 32 & $72 \%$ & CB \\
2 & 40 & $90 \%$ & SB \\
3 & 33 & $75 \%$ & SB \\
4 & 34 & $77 \%$ & SB \\
5 & 37 & $84 \%$ & SB \\
6 & 33 & $75 \%$ & SB \\
7 & 31 & $70 \%$ & CB \\
8 & 36 & $82 \%$ & SB \\
9 & 36 & $82 \%$ & SB \\
10 & 32 & $72 \%$ & CB \\
11 & 38 & $86 \%$ & SB \\
12 & 35 & $79 \%$ & SB \\
13 & 38 & $86 \%$ & SB \\
14 & 37 & $84 \%$ & SB \\
15 & 38 & $86 \%$ & SB \\
16 & 42 & $95 \%$ & SB \\
17 & 25 & $56 \%$ & CB \\
18 & 40 & $90 \%$ & SB \\
Jumlah & $\mathbf{6 3 7}$ & $\mathbf{8 0 \%}$ & $\bar{p}=\mathbf{8 0} \%$ \\
\hline
\end{tabular}

Berdasarkan Tabel 7. hasil penilaian yang diperoleh dari uji coba lapangan total persentase rata-rata mendapatkan nilai sebesar $80 \%$ dengan kriteria sangat baik.

Setelah dilakukan validasi oleh para ahli didapat modul bilingual brgambar berbasis quantum learning telah layak digunakan. Uji coba kelompok kecil dan uji coba kelompok besar untuk mengetahui kelayakan produk modul bilingual bergambar berbasis quantum learning pada materi peluang juga dikatakan kemenarikannya sangat tinggi sehingga tidak dilakukan uji coba ulang. Selanjutnya modul dapat dimanfaatkan sebagai salah satu bahan ajar bagi siswa dan pendidik di SMP/MTs pada materi peluang. 
Desimal, 1 (2), 2018 - 163

Ageng Sandiyanti, Rosida Rakhmawati M

\section{SIMPULAN DAN SARAN}

Kesimpulan yang diperoleh dari penelitian dan pengembangan ini adalah Modul bilingual bergambar berbasis quantum learning pada meteri peluang dihasilkan telah dikembangkan dengan prosedur penelitian dikembangkan menurut model ADDIE yang dikembangkan oleh Dick and Carrey yang meliputi tahap analisys, design, development, implementasion, dan evaluation. Modul pembelajaran yang dikembangkan telah melalui tahap validasi oleh ahli materi, ahli media, ahli bahasa dan di uji coba pada siswa di SMPIT Azzahra. Rata-rata pesentase penilaian dari ahli materi yaitu 83,33\% masuk dalam kriteria "sangat baik", rata-rata pesentase penilaian dari ahli media yaitu $85 \%$ masuk dalam kriteria "sangat baik" dan rata-rata pesentase penilaian dari ahli bahasa yaitu 78,67\% masuk dalam kriteria "sangat baik". Kualitas modul pembelajaran telah mencapai standar kelayakan modul pembelajaran dari hasil penilaian ahli materi, ahli media, ahli bahasa dan siswa. Modul bilingual bergambar berbasis quantum learning pada meteri peluang kelas VII memperoleh nilai persentase dari respon siswa sebesar $80 \%$ dengan kriteria sangat menarik dan memperoleh nilai persentase dari pendidik sebesar $84 \%$ dengan kriteria sangat menarik.

Modul bilingual bergambar berbasis quantum learning hanya menyajikan meteri peluang sehingga peniliti menyarankan untuk pengembangan modul bilingual bergambar berbasis quantum learning selanjutnya dapat dikembangkan dengan materi yang lebih luas dan lebih baik lagi.

\section{DAFTAR PUSTAKA}

Anggoro, B. S. (2015). Pengembangan Modul Matematika Dengan Strategi Problem Solvin Guntuk Mengukur Tingkat Kemampuan Berpikir
Kreatif Matematis Siswa. Al-Jabar: Jurnal Pendidikan Matematika, 6(2), 121-130.

Anggraini, R. (2016). Pengembangan Bahan Ajar Materi Trigonometri Berbantuan Software iMindMap pada Siswa SMA. Al-Jabar: Jurnal Pendidikan Matematika, 7(1), 3947.

Hamdani. (2011). Strategi Belajar Mengajar. Bandung: Pustaka Setya.

Linto, R. logina, Elniati, S., \& Rizal, Y. (2012). Kemampuan Koneksi Matematis dan Metode Pembelajaran Quantum Teaching dengan Peta Pikiran. Jurnal Pendidikan Matematika, 1(1), 8387.

Mustari, M., \& Sari, Y. (2017). Pengembangan Media Gambar Berupa Buku Saku Fisika SMP Pokok Bahasan Suhu dan Kalor. Jurnal Ilmiah Pendidikan Fisika AlBiruni, 6(1), 113. https://doi.org/10.24042/jpifalbir uni.v6i1.1583

Nugroho, A. A., Putra, R. W. Y., Putra, F. G., \& Syazali, M. (2017). Pengembangan Blog sebagai Media Pembelajaran Matematika. AlJabar: Jurnal Pendidikan Matematika, 8(2), 197-204.

Purwanti, R. D. (2016). Pengaruh Pembelajaran Berbatuan Geogebra terhadap Pemahaman Konsep Matematis ditinjau dari Gaya Kognitif. Al-Jabar: Jurnal Pendidikan Matematika, 7(1), 115-122.

Puspita, M. (2014). Pengembangan Modul Bilingual Bergambar Terhadap Minat Belajar Siswa Pada Tema Energi di Alam Sekitar. Unnes Science Education Journal, 3(2), 476-480.

Sari, F. K., Farida, F., \& Syazali, M. (2016). Pengembangan Media Pembelajaran (Modul) berbantuan Geogebra Pokok Bahasan Turunan. Al-Jabar: Jurnal Pendidikan 
Desimal, 1 (2), 2018 - 164

Ageng Sandiyanti, Rosida Rakhmawati M

Matematika, 7(2), 135-151.

Sari, Y. K., Mulyani, S., Susilowati, E., \& Ridlo, S. (2013). Efektivitas Penerapan Metode Quantum Teaching Pada Pendekatan Jelajah Alam Sekitar (JAS) Berbasis Karakter dan Konservasi. Unnes Journal of Biology Education, 2(2), 165-172.

Sugiyono. (2013). Metode Penelitian Pendidikan. Bandung: Alfabeta.

Supriadi, N. (2015). Mengembangkan Kemampuan Koneksi Matematis Melalui Buku Ajar Elektronik Interaktif (BAEI) yang Terintegrasi Nilai-Nilai Keislaman. Al-Jabar: Jurnal Pendidikan Matematika, 6(1), 63-73.

Susanti, H. M. (2013). Penerapan Pembelajaran Quantum Teaching dalam Peneingkatan Pembelajaran Matematika Tentang Bangun Ruang Siswa Kelas V SD Negeri Mewek. Kalam Cendikia, 4(2), 112-119.

Tegeh, I. M., Jampel, I. N., \& Ketut Pudjawan. (2014). Model Penelitian Pengembangan (1st ed.). Yogyakarta: Graha Ilmu. 